\title{
Interaksi antara Tingkat Ketersediaan Air dan Varietas terhadap Kandungan Prolin serta Pertumbuhan Tanaman Kedelai (Glycine max L. Merr)
}

\section{Interaction of Water Supply Level and Varieties to Prolin Content and The Growth of Soybean (Glycine max L. Merr)}

\author{
Eko Wahono ${ }^{1}$, Munifatul Izzati ${ }^{2 *}$, Sarjana Parman ${ }^{2}$ \\ ${ }^{1)}$ Program Studi Biologi, Departemen Biologi, Fakultas Sains dan Matematika, Universitas Diponegoro \\ ${ }^{2)}$ Departemen Biologi, Fakultas Sains dan Matematika, Universitas Diponegoro \\ Jl. Prof. Soedarto, SH, Tembalang, Semarang \\ *Email : Munifatul_Izzati@yahoo.com
}

Diterima 3 Desember 2015 / Disetujui 23 Januari 2018

\begin{abstract}
ABSTRAK
Produksi kedelai di Indonesia mengalami penurunan karena kondisi cuaca yang tidak menentu, maka perlu dilakukan penanaman kedelai yang toleran terhadap cekaman kekeringan untuk mengatasi permasalahan ini. Kedelai melakukan adaptasi cekaman kekeringan dengan cara mengakumulasi prolin untuk melindungi sel dari kerusakan. Tujuan penelitian ini adalah untuk mengetahui pengaruh tingkat ketersediaan air terhadap pertumbuhan dan kandungan prolin pada tanaman kedelai varietas Wilis dan Grobogan. Penelitian ini dilaksanakan di Greenhouse Gombel Lama dan di Laboratorium Biologi Struktur dan Fungsi Tumbuhan Jurusan Biologi FSM Undip. Rancangan yang digunakan adalah Rancangan Acak Lengkap (RAL) pola faktorial, 2 faktor yaitu tingkat ketersediaan air dan varietas dengan 6 perlakuan dan 3 pengulangan. Analisis data menggunakan Analisis of Variance (Anova) dilanjutkan uji beda nyata Duncan Multiple Range Test (DMRT) pada taraf signifikasi 95\%. Parameter yang diamati adalah kandungan Prolin dan pertumbuhan (tinggi tanaman, berat basah dan kering tajuk, berat basah dan kering akar). Hasil penelitian menunjukkan tingkat ketersediaan air berpengaruh terhadap kandungan prolin dan pertumbuhan. Ketersediaan air terendah menghasilkan kandungan prolin tertinggi, yaitu pada varietas Grobogan sebesar 2,15 $\mu \mathrm{mol} / \mathrm{gr}$ dan Wilis 2,30 $\mu \mathrm{mol} / \mathrm{gr}$. Varietas tidak berpengaruh nyata terhadap kandungan prolin dan pertumbuhan tanaman kedelai, tetapi berpengaruh signifikan terhadap tinggi tanaman dan jumlah daun trifoliat. Varietas Grobogan lebih unggul terhadap cekaman kekeringan dibandingkan Wilis dilihat dari tinggi tanaman dan jumlah daun trifoliat.
\end{abstract}

Kata kunci : prolin, ketersediaan air, kedelai, Glycine max

\begin{abstract}
The Soybean production in Indonesia has decreased due to erratic weather conditions. It is necessary to plant soybeans that are tolerant to drought stress to overcome this problem. Soybean adapt to drought stress by accumulating proline to protect cells from damage. The purpose of this study was to determine the effect of water availability on growth and proline content in soybean. This study was conducted in Greenhouse Gombel Lama and Biology Laboratory Diponegoro University. The design used was a completely randomized design (CRD) with 2 factors these are the level of water availability and soybean plant variety. This research had 6 treatments and 3 replication. Data were analyzed using ANOVA, followed by Duncan's multiple range real difference test. Parameters measured were proline content and plant growth (plant height, fresh and dry weight of shoot and roots). The results show that the level of water availability affect the content of proline and growth. The lowest water availability had the highest prolin content, that was Grobogan variety with 2,15 $\mu \mathrm{mol} / \mathrm{gr}$ of proline content while Wilis variety had $2.30 \mu \mathrm{mol} / \mathrm{gr}$ of proline content. The soybean plant variety not significantly affect the content of proline and plant growth, but significantly affect on plant height and number of leaves trifoliat. Grobogan variety was more adapted to drought stress than Wilis variety.
\end{abstract}

Keywords : proline, water availabyility, soybean, Glycine max 


\section{PENDAHULUAN}

Kedelai merupakan bahan baku makanan yang bergizi, oleh karena itu sangat dibutuhkan oleh hampir semua lapisan masyarakat. Kebutuhan kedelai setiap tahunnya mengalami peningkatan, tetapi jumlah produksinya semakin menurun. Salah satu faktor penurunan produksi kedelai yaitu akibat penurunan luas lahan dikarenakan adanya alih fungsi pemanfaatan lahan dari pertanian menjadi non-pertanian. Selain karena keterbatasan lahan, penurunan hasil kedelai dikarenakan penanaman kedelai biasanya dilakukan pada akhir musim penghujan atau awal musim kemarau.

Kebanyakan lahan pertanian di Indonesia merupakan lahan tadah hujan. Hal ini berpengaruh pada kurangnya ketersediaan air di musim kemarau yang dapat mengakibatkan lahan pertanian menjadi kering. Salah satu upaya penting untuk meningkatkan produksi kedelai di Indonesia adalah melalui perluasan areal tanam pada lahan kering yang potensial untuk segera dimanfaatkan (Pantohardjono, 2005).

Menurut Sloane et al. (1990), kendala terpenting budidaya kedelai pada lahan kering ialah menyangkut ketersediaan air pada musim kemarau, yang sering menyebabkan terjadinya cekaman kekeringan. Penanaman kultivar kedelai yang toleran terhadap cekaman kekeringan menawarkan harapan dapat mengembangkan budidaya kedelai di lahan kering.

Toleransi cekaman kekeringan pada tanaman hampir selalu melibatkan akumulasi senyawa yang dapat melindungi sel dari kerusakan yang terjadi pada saat potensial air rendah (Yusniwati, 2008). Salah satu senyawa yang berperan dalam penyesuaian osmotikal sel adalah prolin. Yoshiba et al., (1997) mengatakan bahwa prolin adalah salah satu osmolitik kompatibel paling umum pada stres air tanaman yang berfungsi dalam pengaturan tekanan osmosis dan akumulasinya di dalam sel yang berperan dalam menjaga kesetimbangan air.

Berdasarkan uraian di atas, maka perlu dilakukan penelitian lebih lanjut mengenai "Interaksi antara ketersediaan Air dan Varietas Terhadap Kandungan Prolin serta Pertumbuhan Tanaman Kedelai (Glycine max L. Merr)". Dengan mengetahui mekanisme dasar fisiologi dan biokimia tersebut, diharapkan bisa membantu dalam program pengembangan varietas kedelai yang lebih toleran terhadap cekaman kekeringan, sehingga dapat meningkatkan produksi kedelai sekaligus memantapkan ketahanan pangan nasional.

\section{METODE PENELITIAN}

Penelitian ini dilaksanakan di Kebun Percobaan Gombel Lama dan Laboratorium Biologi Struktur dan Fungsi Tumbuhan Jurusan Biologi FSM Undip pada bulan Juni dan Juli 2013. Rancangan percobaan yang digunakan adalah rancangan acak lengkap (RAL) pola faktorial, 2 faktor yaitu : 1. Varietas Grobogan dan Wilis 2. Tingkat ketersediaan air FTSW 1, FTSW 0,5 dan FTSW 0,25.

Parameter yang diamati adalah kandungan prolin dan pertumbuhan antara lain tinggi tanaman, jumlah daun trifoliat, berat basah dan berat kering tajuk serta akar. Ketersediaan air merupakan selisih antara kapasitas lapang dengan titik layu permanen (Sutanto, 2005). Berdasarkan metode yang digunakan oleh Heinemann et al. (2011), nilai fraksi air tanah yang tertranspirasi atau FTSW (Fraction of Tranaspirable Soil Water) dapat ditentukan dengan rumus sebagai berikut:

$$
\text { FTSW }=\frac{\text { berat total } n-\text { berat total } n+1}{\text { Ketersediaan air }}
$$

Metode yang digunakan dalam penentuan kadar prolin adalah metode Bates et al. (1973) dengan cara menghitung absorban pada panjang gelombang $520 \mathrm{~nm}$ dengan menggunakan toluen sebagai blanko. Hasil pengamatan absorban selanjutnya dihitung menggunakan rumus sebagai berikut:

$$
\text { Kandungan Prolin }=\frac{(\mu \mathrm{g} \mathrm{prolin} / \mathrm{ml} \mathrm{x} \mathrm{ml} \mathrm{toluen}) / 115,5 \mu \mathrm{g} / \mu \mathrm{mol})}{(\mathrm{g} \mathrm{sampel} / 5)}
$$

Pengukuran berat kering tajuk dan akar dilakukan dengan menimbang berat kering tajuk dan akar setelah dioven pada suhu $60^{\circ} \mathrm{C}$ hingga 


\section{Interaksi antara Tingkat Ketersediaan Air dan Varietas terhadap Kandungan Prolin serta Pertumbuhan Tanaman Kedelai (Glycine max L. Merr)}

beratnya konstan. Data yang diperoleh dianalisis menggunakan ANOVA faktorial dan uji lanjut DMRT pada taraf signifikansi $95 \%$.

\section{HASIL DAN PEMBAHASAN}

\section{Kandungan Prolin}

Hasil pengamatan menunjukkan bahwa interaksi antara varietas dengan tingkat ketersediaan air (FTSW) tidak berpengaruh signifikan terhadap kandungan prolin. Perbedaan tingkat ketersediaan air berpengaruh signifikan terhadap kandungan prolin tanaman kedelai. Peningkatan kandungan prolin bebas dikarenakan adanya cekaman kekeringan pada tanaman. Menurut Bates et al,. (1973), kandungan prolin akan meningkat seiring dengan kenaikan tingkat cekaman kekeringan pada suatu tanaman. Penelitian yang telah dilakukan oleh Yusniwati (2008) menunjukkan hasil peningkatan kandungan prolin yang nyata pada tanaman dalam kondisi cekaman kekeringan dibanding pada kondisi tanpa cekaman.

Hasil penelitian menunjukkan adanya pengaruh nyata tingkat ketersediaan air terhadap kandungan prolin. Menurut Yoshiba et al,. (1997), hal ini dikarenakan prolin berfungsi untuk mengatur tekanan osmosis dan akumulasinya didalam sel berperan dalam menjaga kesetimbangan air. Akumulasi prolin dalam kondisi stress menurunkan tekanan air sel sehingga tanaman tetap mampu menyerap lebih banyak air dan hara dari tanah (Dingkuhn et al., 1991).

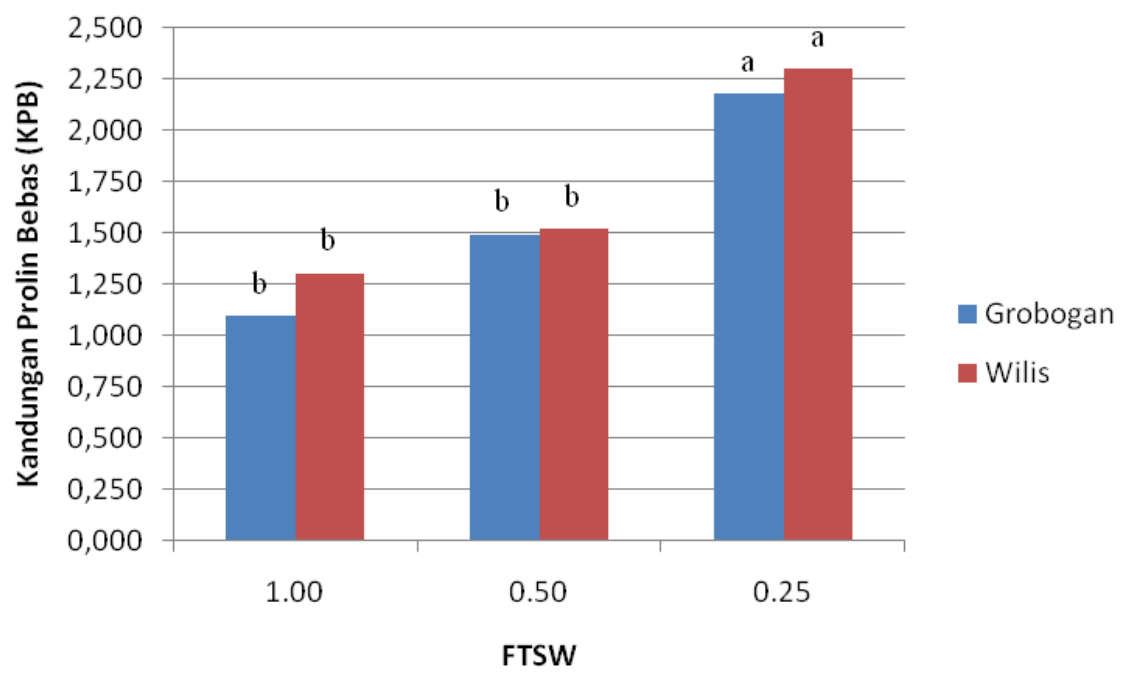

Gambar 1. Kandungan prolin tanaman kedelai setelah perlakuan

Selain berfungsi sebagai pengatur tekanan di dalam sel, prolin juga berperan dalam mengurangi radikal bebas di dalam sel sehingga kerusakan yang disebabkan cekaman oksidatif dapat dicegah (Hong et al,. 2000). Menurut Pritchard et al. (2000), tanaman yang mendapat cekaman akan melakukan perlindungan dengan membentuk enzim senyawa antioksidan untuk mengurangi tingkat detoksifikasi Reactive Oxygen Species (ROS) secara langsung maupun tidak langsung di dalam sel tanaman. Enzim-enzim yang terbentuk inilah yang akan dilindungi oleh prolin dari denaturasi, sehingga upaya pencegahan kerusakan dapat berlangsung secara optimal (Konstantinova et al,. 2002).

\section{Tinggi Tanaman}

Interaksi antara varietas dan tingkat ketersediaan air berpengaruh signifikan terhadap tinggi tanaman kedua varietas. Begitu juga dengan perlakuan cekaman kekeringan, memberikan pengaruh signifikan terhadap tinggi tanaman kedua varietas tersebut. Tanaman kedelai varietas Grobogan cenderung lebih tinggi daripada varietas Wilis, hal ini dikarenakan faktor morfologi. 
Menurut catatan Pusat Penelitian dan Pengembangan Tanaman Pangan tahun 2010, tanaman kedelai varietas Grobogan mempunyai tinggi batang berkisar antara $80-90 \mathrm{~cm}$. Sedangkan kedelai varietas Wilis mempunyai tinggi batang sedang, antara 40-50 cm (Sumarno et al., 1983).

Penurunan tinggi tanaman kedelai varietas Grobogan dan Wilis pada tingkat ketersediaan air yang rendah disebabkan oleh terhambatnya proses pembelahan dan pemanjangan sel. Menurut Mapegau (2006), pertumbuhan tanaman sangat peka terhadap tingkat ketersediaan air karena berkaitan erat dengan turgor, yang mana penurunan turgiditas dapat menghambat pembelahan dan pemanjangan sel sehingga tanaman akan lebih kecil dari ukuran normal.

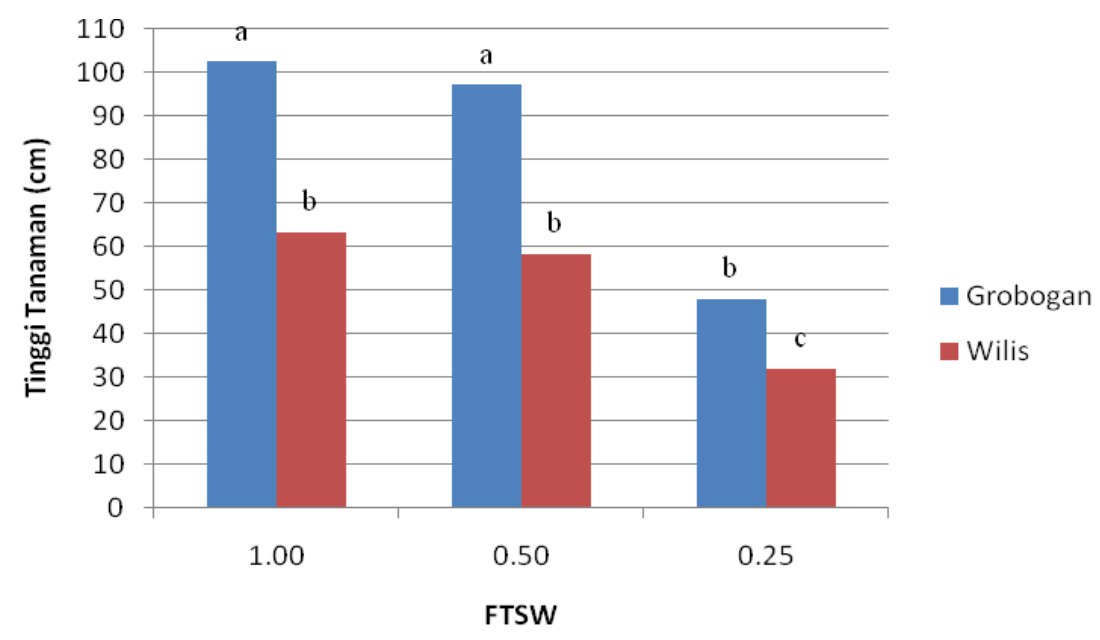

Gambar 2. Tinggi tanaman kedelai setelah perlakuan

Pemberian cekaman kekeringan dapat menghambat pertumbuhan tajuk kedelai, bahkan lebih besar dari pada penghambatan terhadap pertumbuhan akar karena upaya tanaman dalam menjaga keseimbangan air dengan memperkecil luas permukaan tajuk untuk menurunkan laju penguapan dan mempertahankan perkembangan akar sehingga kebutuhan air dapat diatasi (Hamim et al., (1996).

\section{Jumlah Daun Trifoliat}

Perbedaan tingkat ketersediaan air berpengaruh signifikan terhadap jumlah daun trifoliat tanaman kedelai. Kedelai varietas Grobogan dan Wilis tidak menunjukkan adanya perbedaan yang signifikan pada jumlah daun trifoliat, keduanya mempunyai jumlah trifoliat yang hampir sama. Hal ini dimungkinkan karena kedua varietas tersebut mempunyai daya adaptasi yang sama untuk bertahan terhadap kondisi lingkungan sekitar. Levit (1980) mengemukakan bahwa tanaman yang tahan terhadap kondisi cekaman kekeringan akan mengurangi berat dan jumlah daun yang dimilikinya untuk mengurangi besarnya kehilangan air dari tanaman.

Perbedaan kadar air memberi pengaruh terhadap jumlah daun trifoliat. Semakin rendah kadar air yang tersedia, maka semakin sedikit jumlah daun trifoliat tanaman kedelai. Hal tersebut merupakan salah satu cara kedelai untuk dapat bertahan dari cekaman kekeringan, karena tanaman otomatis berkurang jumlah stomatanya agar laju transpirasi lebih kecil (Lestari, 2006).

Menurut Sutrian (2004), stomata umumnya terdapat pada bagian tumbuhan yang berwarna hijau, terutama pada bagian daun. Dalam hal ini, tanaman kedelai bertahan dari pengaruh cekaman kekeringan dengan cara memperkecil jumlah daun trifoliat. 


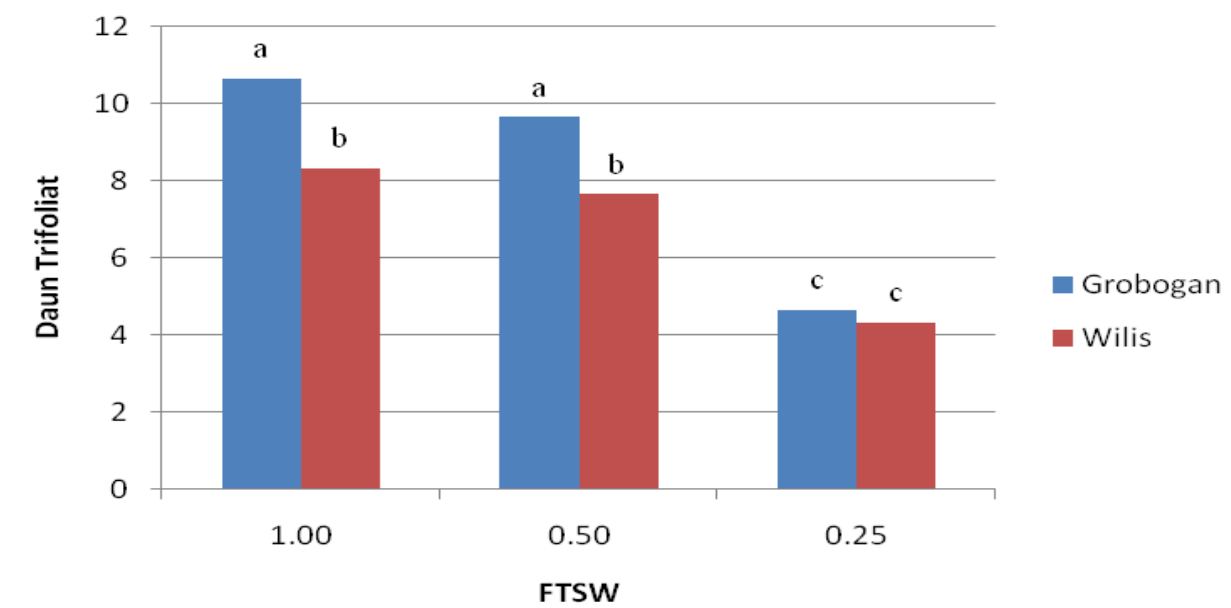

Gambar 3. Jumlah daun trifoliat tanaman kedelai setelah perlakuan

\section{Berat Basah Tajuk}

Interaksi antara varietas dengan tingkat ketersediaan air tidak berpengaruh signifikan terhadap berat basah tajuk. Perbedaan tingkat ketersediaan air berpengaruh signifikan terhadap berat basah tajuk tanaman kedelai. Filter dan Hay (1991) menyatakan bahwa air merupakan senyawa yang dibutuhkan tanaman dalam jumlah besar, lebih dari $80 \%$ bobot basah sel dan jaringan tanaman terdiri dari air. Berkurangnya jumlah ketersediaan air didalam tanah dapat mempengaruhi pertumbuhan vegetatif tanaman kedelai, sehingga pertumbuhan tajuk akan terhambat.

Menurut Salisbury \& Ross (1995), banyaknya klorofil dapat mempengaruhi berat basah tanaman tersebut karena akan menghasilkan fotosintat yang digunakan untuk kelangsungan proses pertumbuhan dan perkembangan tanaman itu sendiri. Laju transpirasi dapat mempengaruhi berat basah yang terkandung pada tanaman akibat menutupnya stomata.

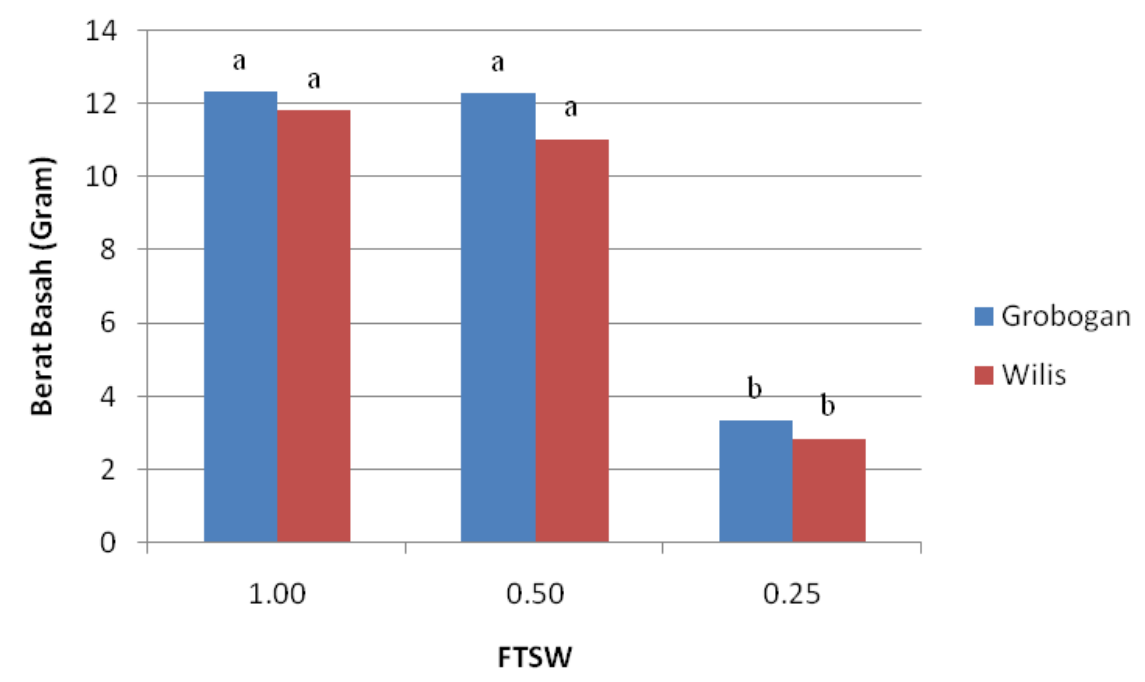

Gambar 4. Berat basah tajuk tanaman kedelai setelah perlakuan

\section{Berat Kering Tajuk}

Perbedaan tingkat ketersediaan air berpengaruh signifikan terhadap berat kering tajuk tanaman kedelai. Hasil berat kering merupakan keseimbangan antara fotosintesis dan respirasi. Fotosintesis dapat meningkatkan berat kering tanaman karena pengambilan $\mathrm{CO}_{2}$ sedangkan 
respirasi dapat menurunkan berat kering tanaman karena melepas $\mathrm{CO}_{2}$ (Gardner dkk., 1991).

Ketersediaan air yang minim dapat menghambat pertumbuhan tanaman, sehingga akan mengurangi hasil fotosintat. Menurut Taiz dan Zeiger (2002), setiap gram pembentukan bahan organik penyusun tanaman rata-rata membutuhkan 500 gram air yang diabsorbsi oleh akar ditransportasikan ke seluruh bagian tanaman.

Bobot kering tajuk mengalami penurunan juga dikarenakan adanya penurunan aktivitas fotosintesis akibat menutupnya stomata untuk menghindari pelepasan air yang berlebihan. Hasil fotosintesis selanjutnya dikirim ke seluruh bagian tanaman melewati floem dengan bantuan air, sehingga jumlah ketersediaan air yang sedikit dapat menghambat transport fotosintat di dalam tanaman (Taiz dan Zeiger, 2002).

Menurut Kozlowsky (1991), perbedaan biomassa dipengaruhi oleh besarnya fotosintat yang dihasilkan. Ketersediaan air yang lebih banyak mempengaruhi pertumbuhan yang lebih tinggi dan juga berat kering yang lebih tinggi. Selain itu, rendahnya kadar air menyebabkan kandungan hara yang ada di dalam tanah sulit untuk diserap oleh akar tanaman. Unsur hara dan mineral merupakan bahan penyusun bahan organik tanaman. Berkurangnya suplai hara yang larut bersama air manyebabkan pembentukan bahan organik tanaman semakin berkurang, sehingga berat kering tajuk secara langsung menurun (Ashri, 2006).

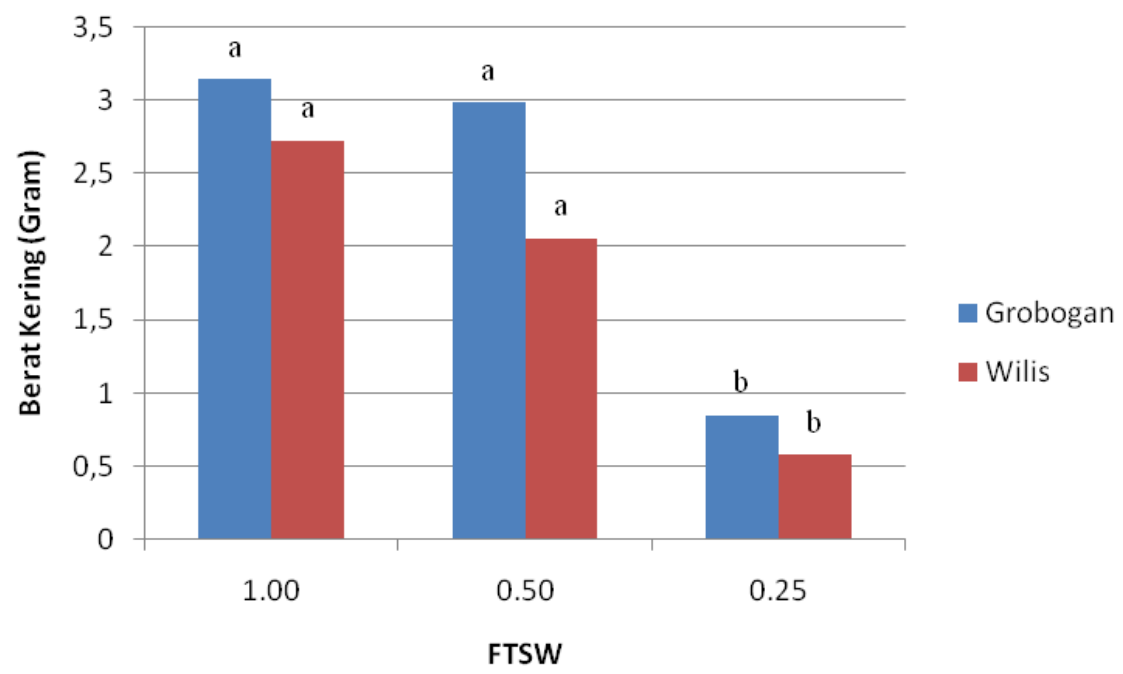

Gambar 5. Berat kering tajuk tanaman kedelai setelah perlakuan

\section{Berat Basah Akar}

Interaksi antara varietas dengan tingkat ketersediaan air tidak berpengaruh signifikan terhadap berat basah akar. Perbedaan tingkat ketersediaan air berpengaruh signifikan terhadap berat basah akar tanaman kedelai kedua varietas.

Pertumbuhan akar kedelai dipengaruhi oleh kadar air yang tersedia, baik pada varietas Wilis maupun Grobogan. Semakin sedikit kadar air yang tersedia maka semakin rendah berat basah akar tanaman kedelai tersebut. Hal ini disebabkan karena terganggunya proses transpirasi dan fotosintesis akibat rusaknya asam amino, enzim dan protein yang berperan pada proses tersebut (Pugnaire et al., 1999).

Selain dipengaruhi oleh gangguan pertumbuhan, turunnya berat basah juga dikarenakan oleh turgiditas sel akar yang tidak maksimal akibat rendahnya kandungan air yang ada di dalam tanah. Ketika kandungan air di dalam tanah sangat rendah, maka potensial air tanah akan mengalami penurunan, sehingga proses penyerapan air oleh akar juga mengalami penurunan. Adanya aliran air terjadi ketika ada perbedaan potensial, yang mana berpindah ke potensial air yang lebih rendah, sehingga akar tanaman akan tetap mempertahankan kondisi 


\section{Interaksi antara Tingkat Ketersediaan Air dan Varietas terhadap Kandungan Prolin serta Pertumbuhan Tanaman Kedelai (Glycine max L. Merr)}

potensial airnya lebih rendah dari pada kondisi lingkungan sekitar, dalam hal ini adalah tanah, agar air dapat diserap oleh akar (Kramer dan Boyer, 1995).

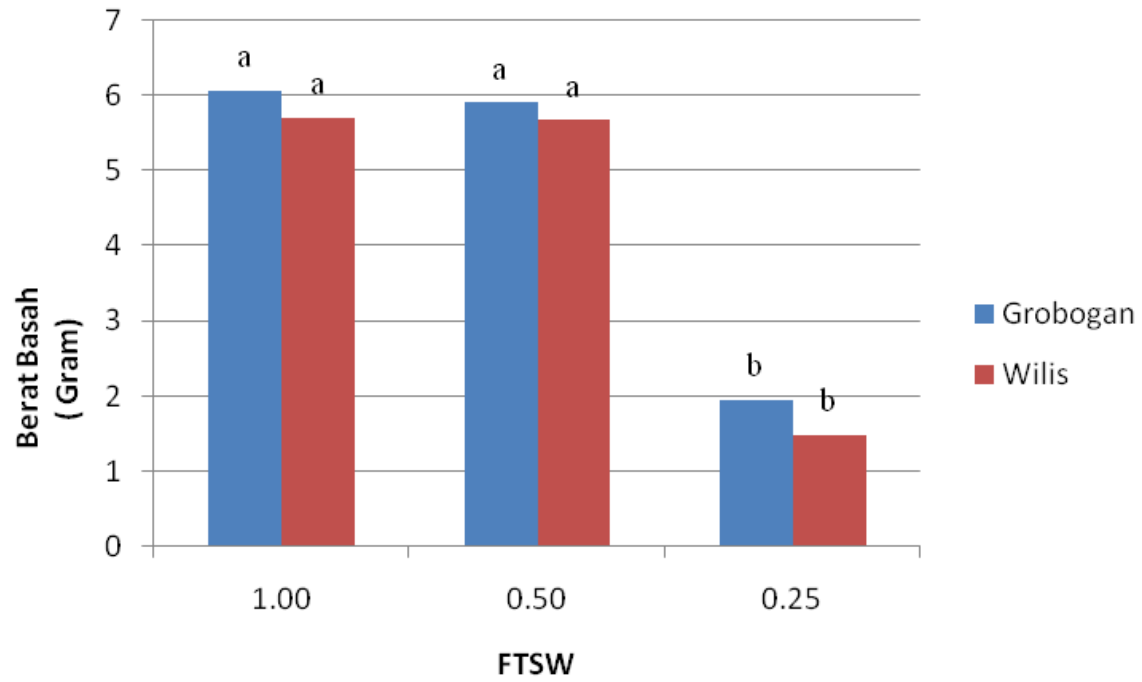

Gambar 6. Berat basah akar tanaman kedelai setelah perlakuan

\section{Berat kering akar}

Hasil pengamatan menunjukkan bahwa interaksi antara varietas dengan tingkat ketersediaan air tidak berpengaruh signifikan terhadap berat kering akar. Perbedaan tingkat ketersediaan air berpengaruh signifikan terhadap berat kering akar tanaman kedelai varietas Grobogan maupun Wilis.

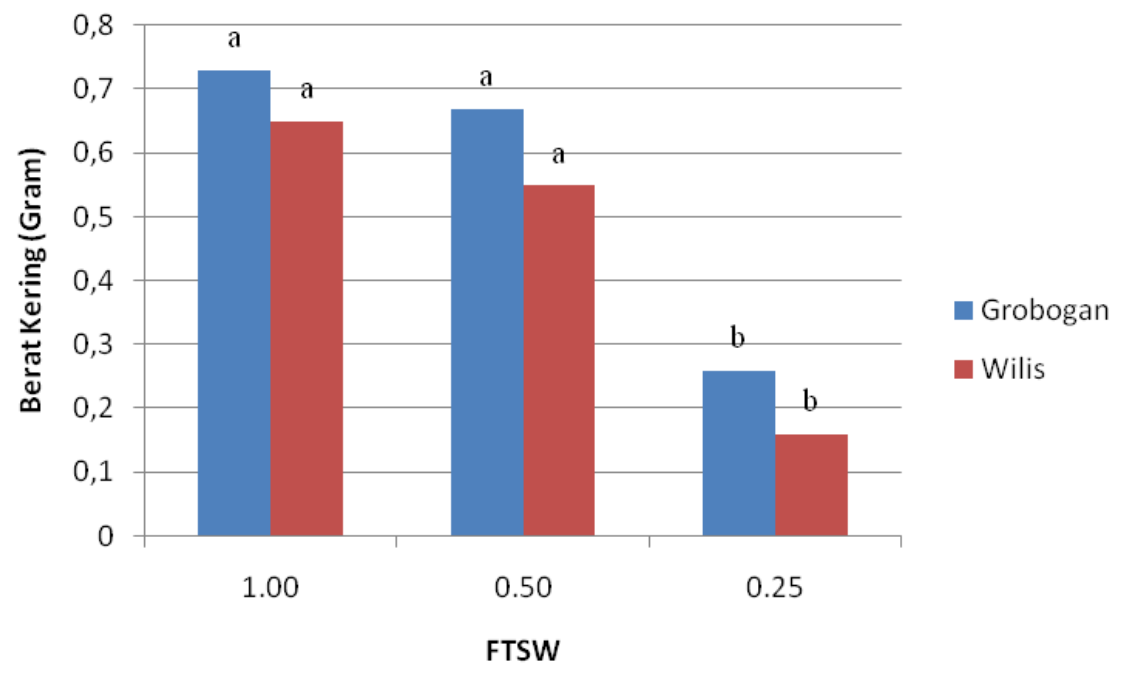

Gambar 7. Histogram berat kering akar tanaman kedelai setelah perlakuan

Hasil penelitian menunjukkan adanya pengaruh nyata tingkat ketersediaan air terhadap berat kering akar. Penurunan berat kering akar seiring dengan semakin minimnya ketersediaan air disebabkan karena laju fotosintesis yang terhambat. Hanum et al. (2007) melaporkan bahwa tehambatnya pertumbuhan perakaran disebabkan karena tanaman tidak mampu mengatur pertumbuhannya secara sempurna akibat dari kurangnya bahan organik yang dihasilkan, sehingga secara langsung dapat menurunkan berat kering akar. 
Pembentukan jaringan perakaran dibutuhkan karbohidrat dalam jumlah besar yang kemudian dikirim melalui floem sebagai sumber energi untuk perkembangan zona apikal akar yang dapat membantu proses pertumbuhan akar (Taiz dan Zeiger, 2002).

\section{KESIMPULAN}

Tingkat ketersediaan air berpengaruh signifikan terhadap kandungan prolin dan pertumbuhan tanaman kedelai varietas Grobogan maupun Wilis, sedangkan perbedaan varietas tidak berpengaruh signifikan terhadap kandungan prolin dan pertumbuhan tanaman kedelai, tetapi berpengaruh signifikan terhadap tinggi tanaman dan jumlah daun trifoliat. Varietas Grobogan lebih unggul terhadap cekaman kekeringan dibandingkan Wilis dilihat dari tinggi tanaman dan jumlah daun trifoliate.

\section{DAFTAR PUSTAKA}

Ashri, K. 2006. Akumulasi Enzim Antioksidan dan Prolin Pada Beberapa Varietas Kedelai Toleran dan Peka Cekaman Kekeringan. Thesis. Program Pasca Sarjana. Institut Pertanian Bogor. Bogor.

Bates, I. S. 1973. Rapid Determination of Free Proline for Water Stress Studies. Plant and Soil. 39: 205-207.

Dingkuhn, M., et al. 1991. Concepts for A New Plant Type for Direct Seeded Flooded Tropical Rice. Pages 17 -38. In: Direct Seeded Flooded Rice in the Tropics. IRRI. Los Banos, Philippines.

Filter A. H. dan Hay. R. K. M. 1991. Fisiologi Lingkungan Tanaman. UGM Press. Yogyakarta.

Gardner, F. P., Pearce, R. B. and Mitchell, R. L. 1991. Fisiologi Tanaman Budidaya (Diterjemahkan oleh: Herawati Susilo). Universitas Indonesia Press. Jakarta.

Hanum, C. dkk. 2007. Pertumbuhan Akar Kedelai pada Cekaman Alumunium, Kekeringan dan Cekaman Ganda Alumunium dan Kekeringan. Agritop (26) 1: 13-18.
Heinemann, A. B., Stone, L. F., Fageria, N. K. 2011. Transpiration Rate Respone to Water Deficit during Vegetative and Reproductive Phases of Upland Rice Cultivars. Sci. Agric Piracicaba 1(68): 24-30.

Hong Z, Lakkineni K, Zhang Z, Verma DPS. 2000. Removal of Feedback Inhibition of D1-Pyrroline-5- Carboxylate Synthetase Results in Increased Proline Accumulation and Protection of Plants from Osmotic Stress1. Plant Physiology, 122 : 1129-1136.

Konstantinova T, Parvanova D, Attanassov A, Djilianov D. 2002. Freezing Tolerant Tobacco, Transformed To Accumulate Osmoprotectants. Plant Science 163 : 157 164.

Kozlowsky, T.T. 1991. Water Deficit and Plant Growth. vol. VI. Woody Plant Communities. Academy Press. New York.

Kramer, P.J. and Boyer J.S. 1995. Water Relations of Plantand Soil. San diego. Academic Press.

Lestari, E.G. 2006. Hubungan antara Kerapatan Stomata dengan Ketahanan Kekeringan pada Somaklin Padi Gajahmungkur, Towuti dan IR 64. Biodiversitas vol.7, N0 1: 44-48.

Levitt J. 1980. Responses of Environmental stresses Vol II. New York. Academika Press.

Pantohardjono, S. 2005. Upaya Peningkatan Produksi Produksi Kedelai Melalui Perbaikan Teknologi Budidaya. Dalam Pantohardjono, et al. (penyunting). Analisan dan Opsi Kebijakan Penelitian dan Pengembangan Tanaman Pangan. Monograf No.1 2005 Puslitbang Bogor

Perez-Molphe-Balch EM et al. 1996. Effects of Water Stress on Plant Growth and Root Proteins in Three Cultivars of Rice (Oryza Sativa) with Different Levels of Drought Tolerance. Physiol plant 96: 284-290.

Pritchard SG, Ju Z, Santen EV, Qiu J, Weaver DB, Prior SA, Roger H. 2000. The Influenc of elevated $\mathrm{CO}_{2}$ on the activities of antioxidative enzymes in two soybean 
genotypes. Aust J Plant Physiol 27 : 10611068 .

Pugnaire, F.I., L. Serrano dan J. Pardos. 1999. Constraints by water stress on plant growth. Dalam: Passarakli, M. (Ed.). Handbook of Plant and Crop Stress. 2nd edn, Revised and expanded. Marcel Dekker Inc, New York, Basel.

Salisbury, F.B. dan C.W. Ross. 1995. Fisiologi Tumbuhan Jilid I. Edisi Keempat. Penerbit ITB. Bandung.

Sloane RJ, Patterson RP, Carter TE. 1990. Field Drought Tolerance of A Soybean Plant Introduction. Crop Sci. 30: 118-123.

Sumarno dkk. 1983. Pembentukan Varietas Unggul Kedelai “Wilis”. Bul. Agr. Vol. XV No. 3.
Sutanto, R. 2005. Dasar-Dasar Ilmu Tanah. Kanisius. Yogyakarta.

Sutrian, Y. 2004. Pengantar Anatomi Tumbuhtumbuhan. Jakarta: Rineka Cipta.

Taiz, L. dan Zeiger, E. 2002. Plant PhysiologyThird edition. Sinaue associaties Inc. Publisher. Massachussetts. 609

Yoshiba et al., 1997. Regulation of Level of Proline as an Osmolyte in Plant under Water Stress. 38(10): 1095-1102.

Yusniwati. 2008. Galur Cabai Transgenik Toleran Kekeringan dengan Gen P5CS Penyandi Enzim Kunci Biosintesis Prolina: Regenerasi dan Karaktrisasi Regenerasi. Disertasi. Institut pertanian Bogor. 